\title{
Juventude e religião, sinais do tempo experimentado
}

Regina Novaes*

\section{Resumo}

Em um momento histórico em que a incerteza atravessa a condição juvenil e no qual as novas tecnologias de informação e comunicação modificam relações no interior do campo religioso, este artigo - inspirado em Mannhein - se propõe a refletir sobre “o tempo religioso experimentado" por jovens de hoje. A partir de pesquisa realizada em sites, blogs e canais do youtube, são analisadas situações, sentimentos e motivações de jovens que falam publicamente sobre sua fé. 0 objetivo é apreender elementos significativos das "eras subjetivas" que distinguem adultos e jovens ampliando possibilidades de escolhas religiosas.

\section{Palavras-chave}

Gerações. Subjetividades. Escolhas religiosas.

\section{Abstract}

In a historic moment, in which uncertainty crosses the youth condition and in which new information and communication technology changed relationships within the religious field, this article - inspired in Mannheim - intends to reflect on "the experienced religious time" by today's youth. From a research carried out in websites, blogs and YouTube channels, I have analyzed situations, feelings and motivations with young people who speak publicly about their faith. The aim is to apprehend significant elements of the "subjective eras" that distinguish adults and young people, amplifying the possibilities of religious choices.

\section{Keywords}

Generations. Subjectivities. Religious Choices.

\footnotetext{
* Regina Novaes é antropóloga e pesquisadora CNPq. Atualmente, é professora visitante do Programa de Pós-Graduação em Educação da Universidade Federal do Estado do Rio de Janeiro (UNIRIO). E-mail: novaes-regina@uol.com.br .
} 


\section{Apresentação}

"Diferentes gerações vivem ao mesmo tempo. Mas como o tempo experimentado é o único tempo real, todas, na verdade, vivem em eras subjetivas bastante distintas qualitativamente."

(Karl Mannheim, O Problema das Gerações, 1982)

Inspirado por essa reflexão de Mannhein, este artigo se propõe a refletir sobre "o tempo (religioso) experimentado" por diferentes gerações. A ideia é apreender elementos significativos das "eras subjetivas" que distinguem os jovens dos adultos, configurando suas possibilidades de escolhas religiosas.

No Brasil, em um passado não muito distante, era evidente a hegemonia católica imbricada na cultura, legitimada pelo Estado, evidenciada na conformação do território e determinante no calendário dos feriados oficiais. Para gerações passadas, "ser brasileiro e ser católico" soava natural. Nessa configuração, uma parte significativa dos brasileiros omitia (e/ou secundarizava) suas ligações com as religiões de matriz africana e/ou com o espiritismo kardecista. Ao mesmo tempo, os protestantes históricos ou de migração eram considerados "minorias" e quase não ultrapassavam um crescimento vegetativo.

Contudo, transformações na sociedade - e no campo religioso Bourdieu $(1986)^{1}$ - modificaram o "tempo real", no qual foram sendo socializadas as novas gerações. Sem dúvida, a diminuição da transferência geracional do catolicismo, que já estava evidente no Censo de 1991, se confirmou em 2010. Ao mesmo tempo, também o crescimento das denominações pentecostais bem como o aumento daqueles que se declaram "sem religião" modificaram significativamente as estatísticas de pertencimento religioso.

Assim sendo, os jovens nascidos entre 15 e 29 anos atrás, menos católicos do que seus pais, já foram socializados em um cenário no qual se destacam dois processos - até certo ponto - contraditórios. Vejamos.

Por um lado, observam-se mais filiação e mais fixação territorial. Os templos evangélicos pentecostais - que se espalham por todo o país logram conversões, propõem exclusividade de pertencimento, interferem

\footnotetext{
${ }^{1}$ Bourdieu (1986) define campo como um conjunto de práticas e valores específicos, formado por diferentes atores, instituições, discursos e forças em tensão em que tudo adquire sentido em termos relacionais por meio de posições e oposições.
} 
nas paisagens e produzem novos enraizamentos. Por outro lado, observamse desfiliação religiosa e maior movimentação. Os trânsitos entre religiões, as experiências com religiões orientais, arranjos híbridos, os "sem religião que têm fé" apontam para maior fluidez e muitos deslocamentos.

Tais mudanças já não causam grande estranheza para os jovens desta geração. Vivendo em um momento histórico em que o presencial e o virtual se imbricam constituindo-se uma mesma realidade, convivendo com famílias multirreligiosas, os jovens de hoje se movem com mais familiaridade em um jogo menos previsível de percursos e combinações, bem como ampliam o repertório de trajetórias religiosas possíveis.

Certamente, muitas pesquisas ainda deverão ser realizadas para compreender continuidades e mudanças na religiosidade dos jovens de hoje. Nessa perspectiva, e com objetivos bem delimitados, este pequeno artigo se propõe a contribuir para o debate sobre o tema. Para tanto, serão utilizadas informações que circulam em jornais, sites, blogs, canais no Youtube e redes sociais nas quais jovens falam publicamente sobre sua fé. Tais "evidências empíricas publicizadas" serão complementadas por um conjunto de entrevistas que realizei com jovens no Rio de Janeiro e, também, por informações disponíveis na bibliografia sobre religião e juventude. Por esta via, busca-se contribuir para um pouco mais de compreensão sobre o "tempo (religioso) experimentado" (presencial e virtualmente) por jovens de hoje.

\section{Zeca, Ana Paula e Murilo: religiosidades e experiências geracionais}

\subsection{Zeca Veloso ("a fé que me faz bem, em harmonia com minha família")}

Quem imaginaria que Caetano Veloso, famoso cantor e compositor baiano, um dos representantes da contestadora geração Tropicália, teria dois filhos frequentando a Igreja Universal do Reino de Deus, estrela máxima do chamado neopentecostalismo? Essa notícia se destacou nas reportagens sobre a recente turnê musical de Caetano com os filhos Moreno, Zeca e Tom e ganhou bastante repercussão em sites e blogs voltados para assuntos culturais e religiosos ${ }^{2}$.

\footnotetext{
${ }^{2}$ Ver o site: <www.midiagospel.com.br>, Acesso em $1^{\circ}$ de março de 2018.
} 
O pai não se negou a falar sobre o assunto. Caetano contou que veio de família muito católica, ia à missa e não dormia sem antes rezar. Contou também que, quando foi para Salvador, ficou mais próximo do candomblé, onde se iniciou como filho de Oxóssi em casa de mãe Menininha, no Gantois. Confessou também que nunca "incorporou", pois "a razão" não permitiu. Hoje Caetano se diz ateu.

Sobre seu filho mais velho - Moreno - o cantor comenta que ele é "religioso de modo abrangente", "não tem "uma religião específica"; "é candomblecista e católico franciscano com atração pelo hinduísmo." Não sabemos como Moreno responderia à pergunta do Censo do IBGE. Católico? Do Candomblé? Outra religião? Sem religião? Mas em uma pesquisa qualitativa - talvez por conta da atração pelo hinduísmo - poderia ser considerado "nova era" ou "religioso sem religião".

Sobre os dois filhos mais novos, apresentados pelo pai - no palco como "cristãos", Caetano diz: "eu não sou religioso. Mas não tenho medo da religiosidade dos meus filhos". Hoje ambos tocam "na Igreja que frequentam", e o pai diz que foi bem recebido quando foi lá para ouvi-los. Em outro momento, em entrevista ao Estado de São Paulo (25/10/2017), Caetano contou que "foi a babá quem converteu os meninos, quando eles ainda eram adolescentes".

O cantor também afirmou que não vê o crescimento das igrejas no Brasil como algo negativo. Provocado por um repórter sobre a presença dos evangélicos na mídia, respondeu: "a Record não tem mais rabo preso com o Bispo do que a Globo com o Cardeal”. Relativizando, Caetano criticou os preconceitos "pseudochics" em relação aos evangélicos. Mas, por outro lado, também frisou ser contra o que chamou de "fundamentalismo evangélico" que alimenta preconceitos e produz sofrimentos ${ }^{3}$.

Voltando a falar sobre a religiosidade dos filhos, em dado momento, Caetano resumiu: "minha geração teve que romper com a religiosidade imposta, a deles teve que recuperar a religiosidade perdida". Como comparar passado e o presente? Como se sabe, para uma minoria ativa de jovens de gerações anteriores, declarar-se ateu foi uma forma de contestar autoridades em casa, na Igreja, no espaço público. "Ser ateu" compunha o

\footnotetext{
${ }^{3}$ Lembro que o cantor encabeça o Movimento 342, que se opõe ao Movimento Brasil Livre (MBL) e à bancada evangélica em discussões sobre mudanças na Lei Rouanet e sobre a censura a manifestações artísticas.
} 
perfil de uma parte da juventude que se envolveu em atividades políticas e/ou ligadas à "contracultura". Bem como, neste mesmo passado, seria muito difícil encontrar um pai que, declarando-se ateu, aceitasse bem a religião dos filhos.

Voltemos a falar dos filhos. Não vi publicada nenhuma declaração pública do filho mais novo, Tom. Já Zeca, hoje com 25 anos, andou falando sobre sua religião ${ }^{4}$. Suas entrevistas repercutiram muito em vários blogs e sites religiosos e/ou culturais. As frases mais destacadas foram: "Tive o primeiro contato com a fé cristã aos 10 anos. Desde então eu creio". "Desde criança tenho fé. Os hinos da igreja são muito importantes para minha formação musical". "No último ano experimentei uma intensificação da fé, um renascimento" "Isto foi muito importante para minha vida, para eu estar conseguindo fazer esse show hoje". O preconceito religioso "chega em mim, mas a fé me faz tão bem, em harmonia com minha família, que qualquer intolerância não tem importância".

Fé, vida, música, renascimento - palavras usadas por Zeca - também fazem parte do vocabulário de muitos jovens evangélicos. Já a experiência de Zeca de convivência "em harmonia" com diferentes escolhas religiosas, no interior de uma família, tornou-se bem mais comum hoje do que no passado, o que, de modo geral, o aproxima de jovens de sua geração. Porém, existem outros recortes - de classe, renda, gênero, orientação sexual, raça, etnia, local de moradia - que também devem ser levadas em conta quando se busca compreender os significados do pertencimento religioso entre jovens. Neste sentido, importante é atentar para o que ocorre entre jovens moradores de favelas e periferias do mesmo Rio de Janeiro.

\subsection{Ana Paula Lisboa ("somos muito mais que ovelhas")}

No Brasil as denominações evangélicas chegaram às prisões, favelas, conjuntos habitacionais, acampamentos rurais e em territórios periféricos marcados pela pouca presença da Igreja Católica e pela presença precária do Estado. Daí ser muito comum a associação entre pertencimento às igrejas evangélicas e pessoas de pouca escolaridade, vistas quase sempre como seres manipuláveis.

${ }^{4}$ O Globo, 20 de dezembro de 2017; e Vogue Brasil, fevereiro de 2018. 
Para pensar sobre o assunto, recorro a Ana Paula Lisboa: mulher, negra, moradora do Complexo da Maré, zona norte do Rio de Janeiro, filha de Oxum. Fez Faculdade de Letras, é DJ, escreve para a Revista AzMina, é colunista do Jornal O Globo. "Somos muito mais que ovelhas" (O Globo, 28/09/2016) é o título de um artigo em que Ana Paula - sem deixar de criticar fortemente as concepções e propostas presentes no Programa do então candidato a prefeito do Rio de Janeiro, Bispo Marcelo Crivella questiona o fato de o candidato ser descartado a priori por sua religião.

(...) quando surgiram as primeiras falas do tipo "não quero um prefeito bispo", bateu um certo rancor. Eu achei o argumento tão raso, parecido com "um evangélico é burro e não é capaz de governar". Pensei nos meus amigos que são da Igreja Universal, pessoas abertas, seres pensantes e questionadores, tem até feminista.

Foi esse "certo rancor" que levou a colunista a falar sobre sua própria história na favela da Maré, onde a Assembleia de Deus tornou-se um espaço importante em sua socialização e sociabilidade.

Eu vivi muitos anos dentro da Igreja Evangélica, e não pense que eu era uma "crente de banco", que entrava e saía despercebida. Pelo contrário, fui ativa no movimento da juventude, fui dos grupos de oração, das equipes de dança e evangelização e também do grupo que passava as madrugadas orando por pessoas em situação de rua e entregando pão com mortadela para elas. Virei muitas noites da última sexta-feira do mês nas vigílias da Assembleia de Deus em Madureira (...).

Não era "crente de banco". Era ativa. Mas, não incorporava totalmente tudo o que ouvia em sua Igreja. "As festas de Cosme e Damião eram, e ainda são, umas das comemorações mais importantes para a minha família, mais importantes até do que o Natal". Por "crescer próxima das religiões de matriz africana", ser "criada na Umbanda", frequentar "festas de santo" (onde "batia palmas, cantava os pontos, comia as comidas e admirava as ekedis"), tinha certeza de que "Orixá não era demônio disfarçado". A "vivência com a cultura popular" (com o jongo, o coco, o samba de roda) também ajudou Ana Paula a relativizar a demonização das expressões culturais afro-brasileiras.

Essas observações nos fazem pensar que as pregações religiosas não 
são nunca absorvidas totalmente como blocos monolíticos. Ou seja, a experiência pessoal e a convivência com a família funcionaram como um filtro cognitivo para selecionar e reinterpretar as mensagens veiculadas na Igreja. O que é dito na Igreja pode ter significados diferentes para um jovem evangélico que nunca frequentou terreiros e para outro que já os frequentou e para quem vive (ou não vive) com parentes próximos que são adeptos da umbanda ou do candomblé.

Da mesma maneira, nas interpretações dos fiéis, pode haver espaços permeáveis para outras visões e narrativas em circulação pela sociedade. Referindo-se a seus amigos da Igreja Universal, Ana Paula diz conhecer "pessoas abertas, seres pensantes e questionadores, tem até feminista". Evidencia-se assim as dissintonias que podem existir entre as declarações públicas de conhecidos pastores evangélicos e as percepções de diferentes segmentos da população evangélica ${ }^{5}$.

Outras modulações no pertencimento religioso também foram, no mesmo artigo, sugeridas por Ana Paula Lisboa. Segundo sua experiência, nas igrejas evangélicas podem conviver: "crente de banco que entra e sai despercebido"; "crentes ativos" e "crente Raimundo, um pé na Igreja e em pé no mundo". Um jovem evangélico pode estar em qualquer uma dessas situações descritas. Entretanto, de maneira geral, nessa fase da vida, os jovens desejam/precisam "ter um pé no mundo".

Para estudar, trabalhar ou desfrutar o tempo livre, os jovens circulam por diferentes espaços e produzem vários pertencimentos. Assim sendo além das experiências anteriores, da convivência familiar e do acesso às narrativas em circulação na sociedade - também as diferentes maneiras de "ser crente" criam possibilidades de selecionar e reinterpretar sentidos e interdições.

Em sua tese de doutoramento sobre religião e amizade entre jovens assembleianos na Baixada Fluminense, Magalhães (2016) confirma o funcionamento da Igreja como um local central para a sociabilidade, convivência e lazer e, também, discorre sobre uma "resistência silenciosa" no que diz respeito a usos e costumes: os jovens separam a roupa de ir à Igreja da roupa do dia a dia, o que lhes dá oportunidade de se sentirem

\footnotetext{
${ }^{5}$ Ver VITAL, Cristina da Cunha e LOPES, Paulo Victor Leite (2012), em que são citadas pesquisas do Datafolha que atestam dissonâncias de opiniões entre pastores evangélicos conservadores midiáticos e a população que se declara "evangélica".
} 
mais próximos de outros jovens na escola, no trabalho, no bairro.

Com efeito, a proliferação de templos evangélicos de diferentes tamanhos modificam territórios e se tornam espaços de sociabilidade onde os jovens fazem amigos e preenchem seu tempo livre. Contudo, sempre vale notar em que circunstancias fazem essa escolha. Ana Paula Lisboa contextualiza:

(...) boa parte da esquerda considerava os crentes burros, bitolados, alienados. Não entendiam, e ainda não entendem, o voto por proximidade e também o papel que a Igreja exerce especialmente nos territórios mais pobres. Esses espaços são muitas vezes a única rede para fora do tráfico, das drogas, da violência doméstica.

Essa observação de Ana Paula está em consonância com relatos que recolhi em entrevistas entre jovens moradores de favelas do Rio de Janeiro marcados pela ausência de serviços públicos, pela violência do tráfico de drogas e pela corrupção das polícias. Ali "ser da Igreja”, " andar com gente da Igreja", "carregar a Bíblia debaixo do braço" aumenta a chance de se manter longe do tráfico e pode ser uma forma de escapar de sempre ser revistado pela polícia.

Consequentemente, as igrejas evangélicas podem se tornar uma espécie de "rede de proteção social" com repercussões na autoestima, no aprendizado da música e, muitas vezes, no acesso ao mundo do trabalho. Contudo, com o "pé no mundo", nem sempre os jovens permanecem por muito tempo nas mesmas igrejas. Muitos ficam apenas temporariamente, até pegar outro rumo. Entre eles, há quem se inicie ou retorne às religiões de matriz afro-brasileira, como foi o caso da própria Ana Paula, que hoje se apresenta como "filha de Oxum".

\subsection{Murilo Araujo ("visibilizar minha existência como negro, gay e católico")}

Para continuar registrando trajetórias juvenis e seus modos de pertencimento religioso, vejamos agora um pouco do que se passa no interior da Igreja Católica. Com esse objetivo, apresento o youtuber Murilo Araujo.

Murilo tem 26 anos, é negro, baiano, hoje mora no Rio de Janeiro. Declara-se cristão, militante e gay. Faz pós-graduação em Linguística Aplicada na UFRJ. Para sua aproximação das causas sociais, contou uma longa vivência na Pastoral da Juventude da Igreja Católica. Hoje é membro do grupo Diversidade Católica e faz parte da Rede Nacional de Grupos 
Católicos LGBT, criada em 2014. Como youtuber, comanda o canal Muro Pequeno, desde 2016.

\begin{abstract}
"Quando eu criei o canal, um dos meus maiores interesses foi exatamente visibilizar essa minha existência enquanto uma pessoa gay e católica (...) porque é muito difícil na cabeça das pessoas encaixar a possibilidade de que uma pessoa seja gay, seja militante, tenha todos os pensamentos que eu tenho lá no canal, e ainda assim, seja religiosa. (...) Tem um problema muito grande aí nesse debate, que as pessoas sempre associam religiosidade com obediência cega, e por isso não concebem como é que uma pessoa gay empoderada pode permanecer dentro de uma religião que indiscutivelmente condena a homossexualidade. E eu quero me colocar na contramão desse debate: eu sou católico, eu gosto de ser católico, e a minha experiência religiosa é uma dimensão da minha vida tão importante quanto a minha sexualidade. Eu me entendo por cristão antes de me entender por gay - e é assim na vida de muita gente. Daí que você pedir pra eu deixar de ser cristão é quase como você pedir pra eu deixar de ser gay. Não vai rolar".
\end{abstract}

"Na contramão", sem "obediência cega", em 2017, com um ano de existência, o canal contabilizava 50 vídeos, 43 mil inscritos e meio milhão de acessos. Hoje - a partir da contribuição financeira de seus inscritos (que são 92.927) e disponibiliza 99 vídeos - o canal já adquiriu uma nova câmera.

No que diz respeito à causa gay, um dos vídeos mais interessantes disponíveis no canal Muro Pequeno se chama "De um filho gay cristão, para pais cristãos de filhos gays." Nele Murilo comenta a notícia do suicídio de um jovem gay em São Paulo, de 16 anos, e discorre sobre o encontro doloroso entre homossexualismo e fé católica. Citando a história bíblica de Esther, fala sobre intolerância doméstica, preconceitos e de sua experiência em acompanhar o sofrimento de jovens gays quando ele era coordenador Pastoral da Juventude e convida os pais de filhos gays e trans para ultrapassar o "muro de estereótipos".

Fala também sobre o sofrimento dos pais que - "mais velhos e com menos expectativas de vida" - têm mais dificuldade de mudar seus pensamentos. Dirige a palavra a esses pais e sugere que procurem grupos e sites de apoio a pais católicos de jovens gays e trans. Murilo fala pouco sobre seus próprios pais. Mas, em um dos vídeos, o youtuber avisa que está gravando da casa dos pais, indicando que logrou o acolhimento em sua própria família. 
No Canal Muro Pequeno, estão disponíveis os vídeos: O que a Bíblia (não) diz sobre homossexualidade e A cura gay e o fundamentalismo cristão. De modo geral, em todos os vídeos, o esforço de Murilo é reunir argumentos baseados em interpretações bíblicas para questionar declarações preconceituosas de pais, padres e pastores. Além da Bíblia, para legitimar sua militância (como negro, gay e católico), ele lança mão de referências bibliográficas utilizadas pelos movimentos sociais.

Ao mesmo tempo, seu ciberativismo também resulta em convites para encontros presenciais em todo o território nacional e mesmo em organizações internacionais. Esses convites, por sua vez, também fornecem material para a web. Desta maneira, encontros presenciais e virtuais se retroalimentam. No Canal temos acesso à sua palestra (em inglês e com legenda disponível em português) intitulada O lugar dos LGTB no Coração de Deus, no Encontro de lideranças religiosas LGBT, na sede ONU em Nova York, em 6/11/2017.

Já no vídeo que foi gravado no Programa Pergunte às Bee 1396, Murilo foi entrevistado por Jéssica, uma das criadoras do Canal, que se apresenta como cristã, "uma lésbica que tem sofrido discriminação na Igreja Católica". Conversando com Jéssica, Murilo conclui: “(...) A Igreja Católica tem que nos aceitar inteiros com nossa sexualidade. Sou gay. E a esquerda também tem que nos aceitar inteiros, com nossa religião". Ou seja, diferentemente do que ocorre no universo evangélico em que as divergências podem levar à fundação novas denominações (como é o caso das chamadas Igrejas Inclusivas), esses jovens, de diferentes orientações sexuais, não abrem mão de lutar por seu pertencimento à Igreja Católica.

Com esse objetivo procuram juntar forças e causas. Essa estratégia fica clara quando a convidada do Canal Muro Pequeno é uma militante do grupo Católicas pelo Direito de Decidir e, no vídeo, ambos se posicionam publicamente a favor da descriminalização do aborto.

Por fim, vale salientar que o combate ao racismo também motiva vários vídeos do Canal. Murilo relata dificuldades em seu próprio processo de se assumir como negro e, hoje, estabelece interlocuções com várias vertentes do movimento. Seus vídeos tratam de temas polêmicos como "preconceito reverso"; "lugar de fala"; o lugar das pessoas "pardas" numa sociedade racista"; "apropriação cultural"; "todo branco é racista?". Destaque especial

\footnotetext{
${ }^{6}$ Ver no Youtube: Canal das Bee (fundado em 18 de outubro de 2016) com 72.190 visualizações em 29 de agosto de 2017.)
} 
para o vídeo no qual se coloca "contra a perseguição às religiões afrobrasileiras". Tema este que aproxima uma parcela de jovens engajados de distintas religiões.

\section{Caminhos cruzados: juventudes e religiosidades}

\subsection{Existem evangélicos e evangélicos...}

Na experiência de Zeca Veloso, descrita no início deste artigo, a família não foi a agência definitiva de sua socialização religiosa. Aliás, causa estranheza que os bem nascidos filhos de um cantor famoso se vinculem à Igreja Universal do Reino de Deus. Existem outras igrejas evangélicas que se distinguem por ter públicos mais seletos. A IURD - via de regra classificada como neopentecostal - se distingue pela "teologia da prosperidade", que oferece esperança de bens materiais para pessoas socialmente deserdadas.

Mas, em matéria de fé, nem tudo cabe na razão instrumental. Coube à babá evangelizar os filhos de seus patrões. Em uma situação tradicional, no mundo cristão, o evangelizador tem mais cultura e poder, e o evangelizado é geralmente alguém mais destituído de posição social. Na situação que estamos analisando, a empregada doméstica - estruturalmente subalterna, trazendo consigo aspectos de liminaridade e communitas - atualizou, em alguma medida, o que Turner chamou de "poder dos fracos".

Até bem pouco tempo, a alusão ao "poder dos fracos" (TURNER, 1974) foi útil para explicar situações em que mães de santo eram procuradas por políticos e ricos que iam aos terreiros em busca de ajuda e proteção. Hoje pode-se indagar até que ponto esse conceito contribui para pensar a capacidade de certos personagens evangélicos converterem pessoas com maior renda e escolaridade.

Certamente, falar em "poder dos fracos" no atual contexto evangélico fica difícil quando lembramos os grandes templos e as rádios e TVs "evangélicas" que se movem dentro da lógica perversa na área da comunicação no Brasil. A Record, que pertence à Igreja Universal do Reino de Deus, é hoje a segunda televisão do país, ainda assim também "aluga" horários em outros canais. Essa prática é seguida por outras igrejas evangélicas que, em concessões públicas, praticam aluguéis sem autorização, fazendo subconcessões e negociações publicitárias. Emissoras como a Bandeirantes, Rede TV! e Gazeta em São Paulo não fecham seus orçamentos sem a venda de horário para as igrejas. 
Contudo, para além da parcela de responsabilidade que grandes igrejas evangélicas têm na manutenção do atual modelo concentrador de comunicação no Brasil, é preciso distinguir o que se passa nas cúpulas do que se passa na chamada "base evangélica", em que o poder simbólico de evangélicos anônimos deve ser relacionado com a presença e/ou a ausência de outros poderes (religioso, econômico e político).

Nesse sentido, a mesma babá que converte os filhos do patrão poderia em tese - ser uma moradora que se sente com o poder para "orar" sozinha ou com sua família - sem necessitar da presença de uma autoridade religiosa - quando começam os tiroteios na favela. "Tiroteio que começa e ninguém sabe como aquilo vai terminar", comentou em entrevista um jovem morador de uma grande favela carioca. Essa liminaridade, que banaliza a morte, também deve ser levada em conta quando relacionamos conversões evangélicas e "poder dos fracos".

Mas, como não estamos falando de estáticas "comunidades de valores", é bom lembrar que "ser jovem da Igreja" pode ser apenas um momento de uma trajetória de vida. Analisando os resultados do Censo, a antropóloga Clara Mafra (2013), inspirada em um texto anterior de Cecília Mariz (2012), chama também a atenção para o fato de a maioria dos jovens "sem religião" ter baixa escolaridade, estar na base da pirâmide e se autoclassificar como pardos. A autora lembra que jovens das periferias, criados aos cuidados de uma mulher evangélica, aprenderam com suas mães/avós/tias que "ter religião" é sinônimo de "frequentar uma igreja".

Assim sendo, por não estarem frequentando uma igreja naquele momento, ao serem indagados, responderiam "não tenho uma religião". Se essa hipótese se confirmar, esses filhos de evangélicos poderiam estar também engrossando as heterogêneas fileiras dos jovens "sem religião" (NOVAES, 2004).

Outra trajetória possível diz respeito a um certo personagem que se diz "evangélico", mas não declara sua denominação. Um "evangélico não determinado" ${ }^{\prime \prime}$, até bem pouco tempo, seria pouco provável em um

\footnotetext{
${ }^{7}$ Segundo o Censo de 2010, os evangélicos somam 22\% da população assim distribuídos: $4 \%$ de evangélicos de missão/históricos, 13,3\% de evangélicos pentecostais e $8 \%$ foram classificados como "evangélicos não determinados". Trata-se de um aumento significativo (com 9,2 milhões de respondentes) daqueles que se autoclassificam apenas como "evangélicos" sem explicitar vínculos institucionais.
} 
"mundo evangélico" que se caracterizava pelo pertencimento exclusivo e pela alta frequência às igrejas locais. Hoje não é impossível pensar em jovens evangélicos/as com pouca adesão comunitária. Pode ser alguém que, em momentos de aflição, busca um culto como um serviço (como sempre ocorreu com as religiões de matriz afro-brasileira). Mas, também, pode ser alguém que circula cotidianamente entre pastores e denominações evangélicas buscando mais fervor e/ ou mais identificação. Ou, ainda, pode ser alguém que assiste a programas de televisão e/ou frequenta grandes eventos públicos (como a Marcha Para Jesus) e/ou "curte" cantores e cantoras gospel fora das Igrejas.

Além disto, para os jovens de hoje, é muito possível circular pelo "universo evangélico" via internet. Pode-se "baixar" cultos e louvores a qualquer hora do dia ou da noite. Em 2017, entrevistei seis jovens evangélicos que afirmaram não ter vínculos institucionais, mas que se mostraram muito familiarizados com o que se passa nas redes sociais, em canais do Youtube, em sites nos quais circulam memes de cunho religioso, clips de hip hop gospel, louvores. Pode-se assim "ser evangélico" de perfil considerado conservador ou progressista sem se submeter ao controle direto de uma autoridade religiosa que, em tese, poderia controlar suas escolhas, ideias e hábitos culturais.

\subsection{Amém e axé: encontros e desencontros entre a fé e as militâncias}

Falemos agora de jovens que têm religião e, ao mesmo tempo, se reconhecem como militantes de causas sociais. Com efeito, as religiões são porosas e não logram impedir (ao menos totalmente) que as questões sociais que alimentam o debate público cheguem aos seus fiéis. Não por acaso, a história do Catolicismo é uma história de embates entre correntes internas. Já no mundo evangélico as disputas pareciam perder o sentido a cada ruptura denominacional. Contudo, nos dias de hoje, segundo a jovem Thamyra Thâmara de Araújo - evangélica, negra, moradora do Complexo do Alemão - há uma "identidade evangélica em disputa".

“(...) Cresci numa Igreja cristã evangélica e foi nesse ambiente que aprendi muito sobre amor e respeito, o que pode soar bastante contraditório! (...) Sou cristã e feminista sim! (...) É preciso que a gente entenda que evangélico não tem uma cara só. Não é sinônimo de Bolsonaros e Felicianos. A identidade evangélica está em disputa e tem uma galera comprometida e engajada 
levantando a bandeira do acolhimento, do respeito à diversidade, do amor fraterno e da dignidade humana".

Essa "galera comprometida e engajada" se comunica por meio de blogs, sites e redes evangélicas e/ ou ecumênicas contrapondo-se às visões racistas, machistas e homofóbicas publicizadas por pastores que têm a visibilidade exacerbada na mídia e em espaços de representação parlamentar. Todo um debate sobre o que é "ser evangélico" se faz presente na Teologia da Missão Integral, na Rede FALE, a Rede Ecumênica de Juventude, bem como as já citadas "igrejas evangélicas inclusivas" ${ }^{8}$, voltadas para a população LGTB.

A perseguição às religiões afro-brasileiras também se tornou um item obrigatório da pauta dessa vertente. "Amém e axé pela paz" (O Globo, 10/10/2017) é o título do artigo do pastor Henrique Vieira, ex-vereador pelo PSOL, fundador da Igreja Batista do Caminho, em Niterói, Estado do Rio de Janeiro. Nesse artigo, esse jovem pastor se posiciona contra a perseguição sofrida por 39 terreiros, 12 deles na Baixada fluminense, entre 15 de julho e 15 de setembro de 2017. Denuncia o racismo que se projeta na dimensão religiosa e que amplia a intolerância contra credos de matrizes africanas. Afirma que os ataques são praticados por pessoas ligadas ao tráfico, mas que o problema vai mais além desses grupos, pois está ligado à "deturpação da mensagem cristã que cria condições para que a violência ocorra com um certo grau de indiferença".

O artigo termina com o seguinte desejo: "como pastor, quero estar ao lado dos povos de santo na luta por uma sociedade livre de fundamentalismo, extremismo e racismo". O combate ao racismo parece ser o principal fator que justifica a aproximação entre esse jovem pastor e os "povos de santo". Vídeos com falas semelhantes do mesmo Pastor Henrique Vieira têm sido muito compartilhadas no Facebook e no Whatsapp. Por outro lado, o combate ao racismo também tem tido repercussões no interior das religiões afro-brasileiras e nas redes sociais onde, por meio da afirmação de sua "ancestralidade", jovens assumem vínculos mais exclusivos com religiões de matriz africana.

\footnotetext{
${ }^{8}$ Sobre o assunto, ver Natividade (2017).
} 
“(...) minha cor é africana muito orgulho de cada traço,/ Desvendo minha história tipo código binário/ Do toque do tambor a energia emana,/Eu trago os orixás das forças africanas./Desde tempo da senzala a resistência está aqui,/Estamos vivos nesta luta os soldados de Zumbi (...)”. (Letra de música, Elivelton Fernandes, 22 anos, Casa de Cultura Cidade Tiradentes, São Paulo).

Ao assumir com exclusividade seus orixás, em encontros presenciais ou por meios digitais, jovens negros convocam orixás africanos para falar em resistência. Na internet, através de site e blogs, podemos ter notícias e acompanhar as atividades da Juventude dos Terreiros ou da Rede de Jovens de Matriz Africana.

Mesmo que ainda não seja estatisticamente significativo, esses posicionamentos modificam relações no interior do campo religioso. Enquanto famosas "mães de Santo" ainda se declaram (e se sentem), em primeiro lugar, católicas e, depois, do candomblé ("sou católica e do povo de santo"), hoje jovens negros questionam esse "duplo pertencimento" que historicamente caracterizou as relações de subordinação ao catolicismo9.

Do lado católico, ainda sob inspiração nos documentos do Concilio Vaticano II (e, atualmente, disputando as bênçãos e a aprovação do Papa Francisco) junto às clássicas questões de terra, moradia e condições de trabalho, acrescentam-se tanto a questão da igualdade racial quanto demandas de mulheres e de grupos de gays e trans. Desta maneira, no combate a preconceitos e discriminações, abrem-se novas possibilidades de comunicação entre jovens evangélicos, católicos e ligados às religiões afro-brasileiros. Vídeos e blogs de youtubers e coletivos disponíveis na internet, utilizando imagens e argumentos muito similares, promovem um dinâmico "ciberecumenismo", informal e prático, sem reuniões para "definir" concepções e estratégias.

Em contraposição, é evidente a consonância (direta ou indireta) entre jovens católicos ligados à Renovação Carismática Católica ${ }^{10}$ e os jovens evangélicos identificados com as pregações e pautas assumidas pelos

\footnotetext{
${ }^{9}$ Por questões de espaço, não trataremos aqui do Espiritismo Kardecista entre jovens, que também merece pesquisa e análises.

${ }^{10}$ Sobre jovens carismáticos, ver Sofiati (2011).
} 
chamados "coronéis da fé"11. Ambos oferecerem efervescência aos fiéis contemporâneos por meio de dons do Espirito Santo e se aliam contra as propostas de descriminalização do aborto, na denúncia do que chamam de "ideologia de gênero", em defesa da família. Em vídeos disponíveis na internet, católicos e evangélicos utilizam as mesmas referências bíblicas para justificar suas posições.

Contudo, as novas articulações tempo/espaço proporcionadas pela internet também abalam as fronteiras que separam "progressistas" e "conservadores". Em entrevista, ouvi relatos de jovens católicos carismáticos gays que, buscando apoio para assumir sua própria orientação sexual, acessam e interagem em sites ligados ao movimento Diversidade Católica. Porém, esses mesmos jovens continuam participando presencialmente de grupos e rituais carismáticos em que não falam sobre sua orientação sexual. Temos aí um espaço católico virtual para acolhimento moral e outro presencial para manifestar a fé e participar de rituais. Sinais dos tempos.

\section{Nota final: juventude, religião e o tempo experimentado}

Os jovens contemporâneos vivem um tempo em que as religiões não são mais as principais fontes distribuidoras de sentido e imagens estáveis da vida entregues de geração a geração pelas autoridades religiosas, reconhecidas como tal. Ao mesmo tempo, hoje não há como falar de juventude sem falar de incertezas. Esse é o sentimento comum que atravessa toda uma geração. Da subjetividade dos jovens de hoje - com diferentes matizes e intensidades de acordo com suas condições de vida - fazem parte vários medos. Como já assinalei em outros artigos, entre jovens contemporâneos (infelizmente) persiste o medo de sobrar por não encontrar seu lugar em um mundo do trabalho restritivo e mutante; o medo de se sentir desconectado neste mundo altamente conectado; o medo de morrer cedo e de maneira violenta. É nesse tempo de incerteza que boa parcela da juventude amplia seu repertório das trajetórias religiosas possíveis. Hoje, embora o catolicismo continue sendo a religião da maioria dos brasileiros, para uma parcela significativa da população, sobretudo para os jovens, as buscas e escolhas religiosas já não

\footnotetext{
${ }^{11}$ A feliz expressão "coronéis da fé" foi usada pelo Pastor Henrique Vieira recentemente em uma atividade pública, também muito compartilhada em vídeo, para designar os pastores que se colocam como porta-vozes de pautas conservadoras.
} 
estão necessariamente relacionadas com desfiliação, desafeição ou oposição ao catolicismo dominante. Posições e oposições são bem mais multifacetadas.

Certamente, trata-se de um processo que comporta continuidades e descontinuidades.

Buscando respostas para questões de fé e de vida, os jovens de hoje fazem escolhas religiosas muitas vezes diferentes de seus pais e irmãos. Surpreendentemente, tal diversidade religiosa não necessariamente faz com que se enfraqueçam laços familiares. Novos arranjos refazem modelos de famílias e também de convivência religiosa entre pais e irmãos que professam distintas religiões. Jovens evangélicos e do candomblé falam sobre discriminação na rua (na escola, no trabalho) e de "aceitação" em casa.

Contudo, paradoxalmente, notícias de maior possibilidade de acolhimento afetivo na vida privada contrastam com o evidente crescimento das discriminações no espaço público. Intolerâncias na família ena sociedade estão em alta e revelam reações conservadoras às conquistas recentes em termos de direitos humanos e diversidade religiosa no Brasil. Certamente a internet produz, alimenta e potencializa posições antagônicas. Porém, poder "acessar" (de casa ou na rua) missas, cultos, demais rituais amplia as possibilidades de autonomia dos jovens de hoje em relação às autoridades e às instituições religiosas. Assim, neste "tempo experimentado", em que o "real" engloba tanto a dimensão presencial quanto a dimensão virtual, surgem muitas mudanças nos modos de pertencimento institucional e nas maneiras de ter fé. As novas tecnologias espalham religiosidades, produzem subjetividades, alimentam oposições e alianças, mas não se fazem apenas em torno de um centro hegemônico produtor de legitimidade. São vários e simultâneos os espaços de negociação que interferem nos relacionamentos familiares e nas relações entre juventudes e religiosidades.

Neste cenário, delineia-se um campo religioso em mutação, menos estruturado e bem mais dinâmico do que no passado. Nele habitam jovens como aqueles que mencionamos no decorrer deste artigo. E, certamente, para sua atual configuração, contribuem iniciativas de jovens que, nas contradições do tempo experimentado, em nome pessoal ou de seus coletivos de referência, retroalimentam sua fé combatendo publicamente discriminações de religião, raça, gênero e orientação sexual. Diante da urgência dessas pautas, só nos resta - lembrando Mannheim - apostar na "potencialidade revitalizadora" dessa parcela da juventude brasileira. 


\section{Referências}

BOURDIEU, Pierre.

(1989). 0 Poder Simbólico. São Paulo, Bertand Brasil.

MAFRA, Clara.

(2013). Números e Narrativas in Debates do NER. Porto Alegre, ano 14, número 24. P. 13-25.

MAGALHÃES, Alexander S.

(2016). Amigo de fé: estudo sobre religião e amizade entre jovens assembleianos na Baixada Fluminense. Tese de doutorado Programa de Pós-Graduação em Ciências Sociais da Universidade do Estado do Rio de Janeiro.

MARIZ, Cecília.

(2012). Pentecostalismo: mudança do significado de ter Religião. Entrevista concedida a Thamiris Magalhães e Graziela Wolfart IHU On line, n. 400.

NATIVIDADE, Marcelo.

(2017). Margens da Política. Estado, direitos sexuais e religiões. Ed. Garamond.

NOVAES, Regina.

(2004). Os jovens "sem religião": ventos secularizantes, "espírito de época" e novos sincretismos. Notas preliminares. Revista Estudos Avançados, v.18, n 52. p 321-330.

MANNHEIM, Karl.

(1982). 0 problema sociológico das gerações. In FORACCHI, Marialice (org.) Sociologia. São Paulo, Ática. p. 67-95.

TURNER, Victor.

(1974). 0 Processo Ritual. Petrópolis, Ed. Vozes.

SOFIATI, Flávio.

(2011). Religião e juventude. Os novos carismáticos. São Paulo, Editora Letras.

VITAL, Cristina da Cunha; LOPES, Paulo Victor Leite.

(2012). Religião e Política: uma análise da atuação de parlamentares evangélicos sobre direitos das mulheres e de LGBTs no Brasil. Rio de Janeiro, Minister.

Recebido em

abril de 2018

Aprovado em

setembro de 2018 